Jurnal Geocelebes Vol. 5 No. 1, April 2021, 23 - 34

\title{
ANALISIS MODEL PENANGANAN GARIS PANTAI DI PANTAI UJUNG PANDARAN KABUPATEN KOTAWARINGIN TIMUR
}

\author{
Sakka ${ }^{1}$, Baharuddin ${ }^{2 *}$ \\ ${ }^{1}$ Program Studi Geofisika, Universitas Hasanuddin, Indonesia. \\ ${ }^{2}$ Program Studi Ilmu Kelautan, Universitas Lambung Mangkurat, Indonesia. \\ *Corresponding author. Email: bahar.osea@gmail.com
}

Manuscript received: 2 January 2020*); Received in revised form: 25 March 2021; Accepted: 1 April 2021

\begin{abstract}
Abstrak
Wilayah Pantai Ujung Pandaran Kecamatan Teluk Sampit Kabupaten Kotawaringin Barat telah mengalami abrasi pantai sebesar 3,262 Ha selama tahun 2014 - 2017. Hal tersebut dapat diantisipasi dengan penanganan baik secara struktur lunak maupun keras. Penelitian ini dilakukan untuk mengetahui model penanganan abrasi Pantai Ujung Pandaran. Berdasarkan hasil analisis menunjukan bahwa penanganan pantai yang terabrasi dapat dilakukan dengan struktur keras melalui sabuk pantai dan revetment. Sabuk pantai dibangun berada pada kedalaman 0,9-1,5 meter MSL dengan lebar celah sejauh 10 - 20 meter, sedangkan revetment di bangun pada celah antara sabuk pantai. Bentuk bangunan tersebut dapat mengurangi abrasi pantai dan akan terbentuk cuspate di belakang bangunan pantai.
\end{abstract}

Kata Kunci: Perubahan garis pantai; penanganan pantai; revetment; sabuk pantai

\begin{abstract}
Ujung Pandaran Coastal Area, Teluk Sampit Subdistrict, Kotawaringin Barat District have experienced coastal abrasion of 3,262 ha during 2014-2017. To anticipate this, it needs to be handled both soft and hard structures. This research was conducted to determine the model for handling the Ujung Pandaran beach abrasion. Based on the results of the analysis shows that the handling of abrasive beaches can be done with hard structures through beach belts and revetments. The beach belt is built at a depth of 0.9 - 1.5 meters MSL with a gap width of $10-20$ meters, while the revetment is built at the gap between the beach belts. With the shape of the building can reduce beach abrasion and cuspate will form behind the beach building.
\end{abstract}

Keywords: coast belt; revetment; shoreline change; shore treatment

\section{Pendahuluan}

Wilayah pesisir merupakan salah satu wilayah yang mengalami degradasi buruk akibat pengelolaan yang tidak terencana dengan baik dalam kurun waktu yang lama. Konversi lahan mangrove menjadi lahan produktif dan pemukiman, serta tekanan aktivitas yang tinggi di wilayah pesisir menyebabkan berbagai dampak seperti erosi/ abrasi, sedimentasi, pencemaran, ROB, penurunan produktivitas perikanan dan berbagai masalah sosial yang memerlukan penanganan secara menyeluruh dan lintas sektor (Djunaedi dan Basuki, 2002). 
Upaya dan langkah adaptasi bagi masyarakat yang hidup dan memiliki penghidupan di wilayah pesisir sangat diperlukan. Ada tiga cara adaptasi yang dapat dilakukan, yaitu: proteksi (melindungi garis pantai), alokasi (memberikan ruang bagi air yang masuk ke darat) serta relokasi (memindahkan permukiman maupun aset lainnya yang terdampak ke lokasi lain). Ketiga metode ini juga dapat dikombinasikan sesuai dengan situasi dan kondisi wilayah yang terdampak.

Wilayah Pantai Ujung Pandaran Kecamatan Teluk Sampit Kabupaten Kotawaringin Barat Provinsi Kalimantan Tengah memiliki tipe pantai yang unik karena merupakan dataran pantai landai yang tumbuh dan berkembang secara alami berupa lidah pasir (sand spit) yang membentang sejauh $\pm 5 \mathrm{~km}$ dengan lebar 10 $-500 \mathrm{~m}$ yang membujur ke arah timur laut dan menghadap ke arah tenggara (Laut Jawa) di bagian selatan dan Teluk Sampit di bagian timur dan utara. Wilayah tersebut merupakan salah satu wilayah yang mengalami dampak perubahan iklim (KKP, 2018), sehingga sebagian besar mengalami abrasi yang cukup besar dan menyebabkan kerusakan permukiman maupun obyek wisata sebagai akibat peningkatan paras muka laut (sea level rise) dan peningkatan frekuensi gelombang besar yang disertai oleh cuaca ekstrim seperti badai.

Berdasarkan data dari RZWP-3-K Provinsi Kalimantan Tengah (DKP, 2017) Pantai Ujung Pandaran merupakan salah satu bagian wilayah pantai dari $460,36 \mathrm{~km}$ atau $(65,40 \%)$ dari total panjang pantai Kalimantan Tengah 703,91 km yang memiliki Indeks Kerentanan Pantai (IKP) kategori tinggi.

Berbagai upaya telah dilakukan untuk penanganan abrasi pantai seperti pemasangan bronjong (revetment), geobag (isian pasir), breakwater dan bangunan pengaman pantai dalam bentuk sabuk pantai Karung Geotekstil Memanjang (KGM). Akan tetapi dari berbagai bangunan tersebut wilayah pantai Ujung Pandaran masih mengalami abrasi. Secara keseluruhan abrasi pada periode tahun 2014 - 2017 untuk posisi HWS (High Water Springs) sebelum dibangunnya sabuk pantai, wilayah pantai yang terabrasi sepanjang $4,819 \mathrm{~km} \quad(85,75 \%)$ lebih dominan dibandingkan yang mengalami sedimentasi hanya $0,801 \mathrm{~km}(14,25 \%)$. Pada periode ini wilayah daratan telah mengalami abrasi sebesar 3,262 ha atau rata-rata $1,087 \mathrm{Ha}$ /tahun dengan lebar abrasi dapat mencapai $1-25 \mathrm{~m}$. Sedangkan pada periode tahun 2017 - 2018 setelah adanya sabuk pantai, abrasi pada posisi HWS hanya sebesar 0,423 Ha. Pada wilayah belakang sabuk pantai abrasi berkisar $1-10 \mathrm{~m}$, sedangkan di luar sabuk pantai berkisar $1-8,5 \mathrm{~m}$ (KKP, 2018).

Analisis abrasi pantai dan penanganannya telah dilakukan oleh beberapa peneliti sebelumnya seperti Supriyanto (2003); Aziz dkk. (2016); Munandar dan Ika (2017). Akan tetapi hasil penelitian tersebut masih dilakukan terpisah dengan antara penyebab dan penanganannya.

Oleh karena itu penelitian ini dilakukan bertujuan untuk memodelkan penanganan abrasi Pantai Ujung Pandaran Kabupaten Kotawaringin Timur, sehingga dapat memberikan rekomendasi untuk mengurangi dampak abrasi yang terjadi.

\section{Metode Penelitian}

Penelitian ini dilaksanakan di Pantai Ujung Pandaran Kecamatan Kumai Kabupaten Kotawaringin Timur Provinsi Kalimantan Tengah Tahun 2018 (Gambar 1). Data data yang dikumpulkan meliputi batimetri, angin, topografi dan pasang surut.

Analisis parameter gelombang laut dalam menggunakan metode SMB (Sverdrup Munk Bretschneider) yang dimodifikasi oleh CHL (2006). Metode ini dikenalkan 
oleh Sverdrup dan Munk pada 1947 dan dilanjutkan oleh Bretschneider pada 1958, yang dibangun berdasarkan pertumbuhan energi gelombang. Kecepatan angin yang digunakan adalah kecepatan angin maksimum harian yang dapat membangkitkan gelombang, yakni kecepatan $\geq 10$ knot dari arah barat, timur, tenggara, selatan dan barat daya, sedangkan arah lain tidak dihitung karena berasal dari darat. Data angin yang diperoleh dari Stasiun Meteorologi Kelas IV H. Asan Kotawaringin Timur tersebut terlebih dahulu dikoreksi menjadi data angin yang dapat membangkitkan gelombang. Analisis yang digunakan adalah mengikuti petunjuk dari CHL (2006).

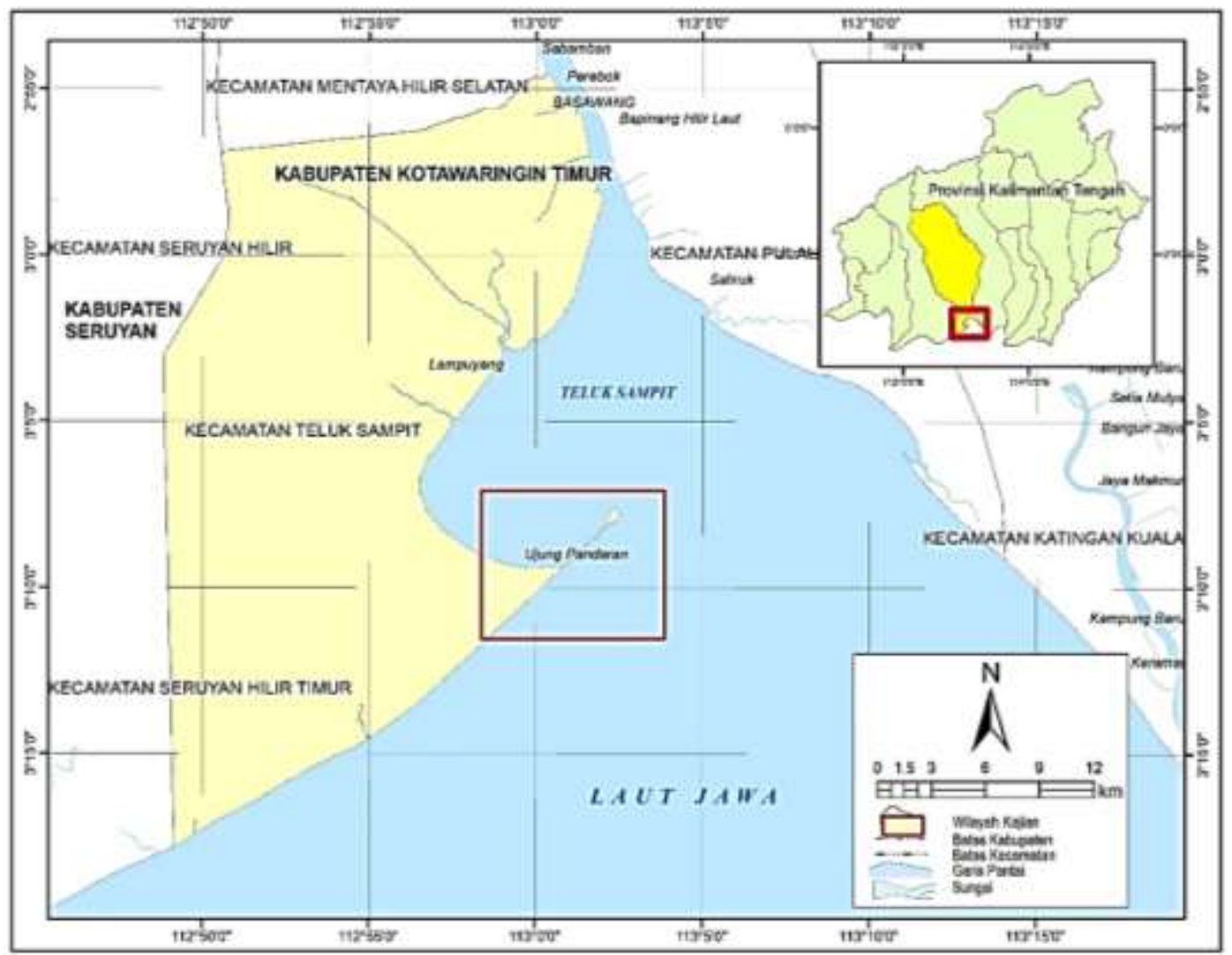

Gambar 1. Lokasi Penelitian.

Parameter gelombang perairan dalam dari metode SMB adalah:

Tinggi gelombang signifikan

$$
H_{s}=1,6 \times 10^{-3} F_{*}^{0,5} \frac{U_{A}^{2}}{g}
$$

$H_{s}=0,243 \frac{U_{A}^{2}}{g}$; untuk $F_{*}>2 \times 10^{4}$ (fully developed waves)

Periode gelombang signifikan:

$$
T_{s}=0,2857 F_{*}^{1 / 3} \frac{U_{A}}{g}
$$

dan $T_{s}=8.13 \frac{U_{A}}{g}$; untuk $F_{*}>2 \times 10^{4} \mathrm{~m}$ (fully developed waves)

Dalam hal ini, $F_{*}=\frac{g F_{\text {eff }}}{U_{A}^{2}}=$ fetch tak berdimensi; $U_{A}=$ faktor tegangan angin; $t=$ durasi pertumbuhan gelombang (detik); $F_{\text {eff }}$ $=$ panjang fetch efektif $(\mathrm{m}) ; g=$ percepatan gravitasi $\left(\mathrm{m} / \mathrm{s}^{2}\right)$.

Analisis model gelombang dilakukan dengan menggunakan model CMS Wave yakni salah satu modul perangkat lunak pemodelan numerik Surface Modeling System (SMS Versi 11). CMS Wave memiliki kemampuan untuk memodelkan 
beberapa fenomena terkait gelombang seperti difraksi, refraksi, Run-up, Set-up, Overtopping, wave generation dan interaksi gelombang dengan struktur pantai (groin, jetty, breakwater).

Perhitungan rencana sabuk ditentukan dengan menentukan beberapa parameter sebagai berikut (Azhar dkk., 2012):

1) Jarak Sabuk dari garis pantai $\left(X_{\text {brw }}\right)$

Jarak $X_{\text {brw }}$ dari pantai ke sabuk dapat diestimasi dengan: $\mathrm{X}_{\mathrm{brz}}<\mathrm{X}_{\mathrm{brw}}<300 \mathrm{~m}$ dengan $\mathrm{X}_{\mathrm{brw}}$ : jarak dari garis pantai yang sebenarnya menuju sabuk $(\mathrm{m})$, dan $\mathrm{x}_{\mathrm{brz}}$ : lebar zona sabuk (m).

2) Panjang Sabuk (Lbrw)

Panjang sabuk dapat diestimasi dengan $\mathrm{L}_{\text {brw }} \approx 0,65 \mathrm{X}_{\text {brw }}$

3) Jarak antar/ gap (Lgap) Sabuk terdekat: Jarak antar sabuk terdekat dijumlahkan dengan $\mathrm{L}_{\text {gap }}=0,5 \mathrm{~L}_{\text {brw }}$

\section{Hasil dan Pembahasan}

\section{Karakteristik Gelombang}

Berdasarkan prediksi gelombang harian di perairan Ujung Pandaran selama tahun 2017 - 2018 dari arah angin yang membangkitkan gelombang menunjukkan bahwa gelombang lebih dominan berasal dari tenggara $(34,50 \%)$, selanjutnya dari arah selatan $23,10 \%$ dan dari barat $17,54 \%$. Akan tetapi tinggi dan periodenya dari arah barat daya lebih besar yakni berkisar 1,0 m - 3,3 m dan 4,4 s - 6,6 s dengan frekuensi hanya $9,65 \%$, sedangkan dari tenggara hanya berkisar $0,9 \mathrm{~m}-2,1 \mathrm{~m}$ dan 4,1 s $-5,5$ s (Gambar 2).

Hasil prediksi gelombang menunjukkan bahwa setiap musim parameter gelombang yang terbentuk terjadi perbedaan. Hal ini disebabkan karena adanya perbedaan faktor yang mempengaruhi dan membangkitkan gelombang seperti kecepatan angin, durasi, arah angin, dan fetch (CHL, 2006). Pada lokasi penelitian diperoleh fetch dari arah selatan lebih besar yakni 194,189 m, sedangkan dari arah barat daya 161,161 m dan tenggara hanya $130,415 \mathrm{~m}$. Akan tetapi kecepatan angin $\left(\mathrm{U}_{\mathrm{W}}\right)$ dari barat daya lebih besar yakni 4,7 - 13,9 m/s, selatan 4,7 $10,4 \mathrm{~m} / \mathrm{s}$ dan tenggara hanya berkisar 4,7 $10,4 \mathrm{~m} / \mathrm{s}$.

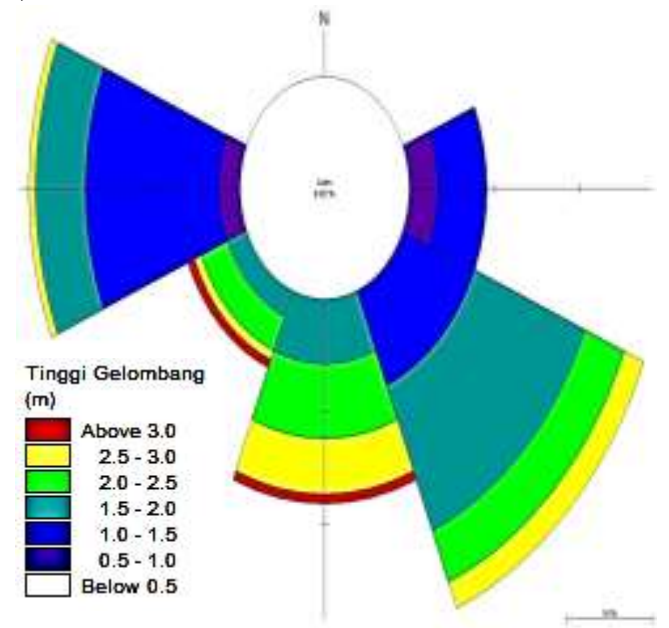

Gambar 2. Mawar gelombang maksimum harian selama tahun 2017 - 2018

Perairan Ujung Pandaran Kabupaten Kotawaringin Timur merupakan daerah yang relatif cukup terbuka dari serangan gelombang laut karena berhadapan dengan Laut Jawa di bagian selatan. Berdasarkan hasil analisis di atas, menunjukkan bahwa bentuk dan tata letak konstruksi bangunan pantai harus memperhatikan faktor dinamika gelombang tersebut. Hal ini akan sangat berpengaruh terhadap bangunan pantai misalnya breakwater atau sabuk pantai.

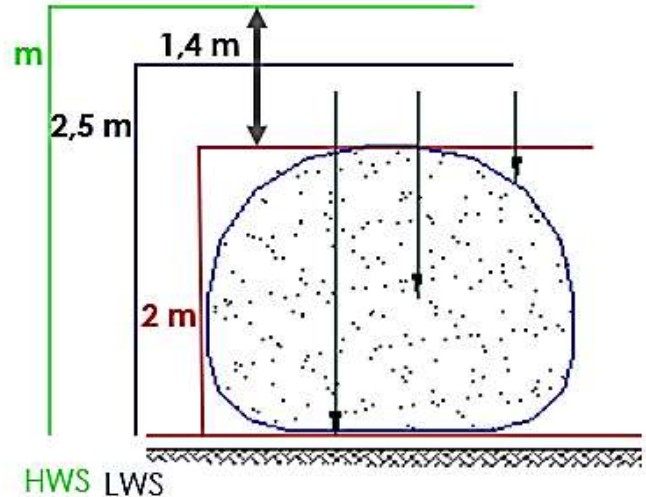

Gambar 3. Posisi sabuk yang dibangun tahun 2017 terhadap kedalaman

Sabuk pantai yang dibangun pada tahun 2017 - 2018 memiliki ketinggian $2 \mathrm{~m}$ yang dipasang pada kedalaman 2 - 2,5 m LWS (Low Water Spring), sehingga pada saat 
HWS sabuk pantai berada pada kedalaman 3,7 - 4,3 m HWS. Kondisi pantai saat HWS dengan adanya sabuk pantai belum berfungsi efektif dalam meredam energi gelombang akibat posisi sabuk masih terendam sedalam $1-1,4 \mathrm{~m}$ (Gambar 3 4).

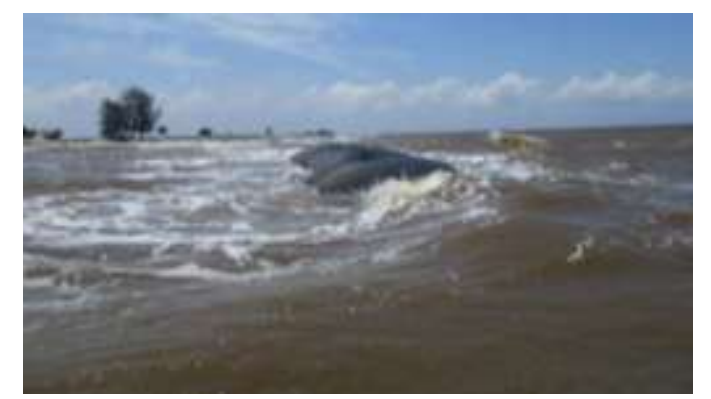

Gambar 4. Gelombang yang masih terjadi di belakang bangunan sabuk pantai (muncul kepermukaan) pada saat posisi air MSL (Mean Sea Level).

Kondisi gelombang cukup tinggi dari arah selatan dan tenggara selama periode Juli 2017 - 2018, berkisar 0,9-2,7 m dengan persentase kejadian $57,6 \%$ dan jika melihat karakteristik pasang surut di wilayah Ujung Pandaran yang bertipe semi diurnal condong keharian tunggal sehingga posisi sabuk akan terendam (di bawah MSL) selama \pm 6 jam -12 jam saat menuju pasang dan menuju surut di atas MSL. Dengan demikian selama waktu tersebut, jika gelombang yang terjadi $>1 \mathrm{~m}$ maka gelombang akan pecah di daerah garis pantai pasang tertinggi, sehingga menyebabkan abrasi di sepanjang pantai Ujung Pandaran.

Hasil yang diperoleh tersebut sesuai dengan hasil permodelan CMS Wave yang dilakukan baik saat posisi HWS maupun MSL, sebagaimana diperlihatkan pada Gambar 5 dan 6. Dengan input gelombang dari laut dalam sebesar $2 \mathrm{~m}$, setelah mengalami tranformasi maka saat di wilayah sabuk pantai gelombang akan pecah setinggi $1,9 \mathrm{~m}$ dan di belakang bangunan menurun $0,9 \mathrm{~m}$ dan gelombang tersebut akan menjalar terus ke pantai dan kemudian akan pecah kembali. Sedangkan saat MSL, gelombang akan mengalami penurunan cukup drastis di belakang bangunan $(<50 \%)$. Untuk gelombang diantara celah bangunan sabuk pantai akan pecah sampai ke daerah pantai.
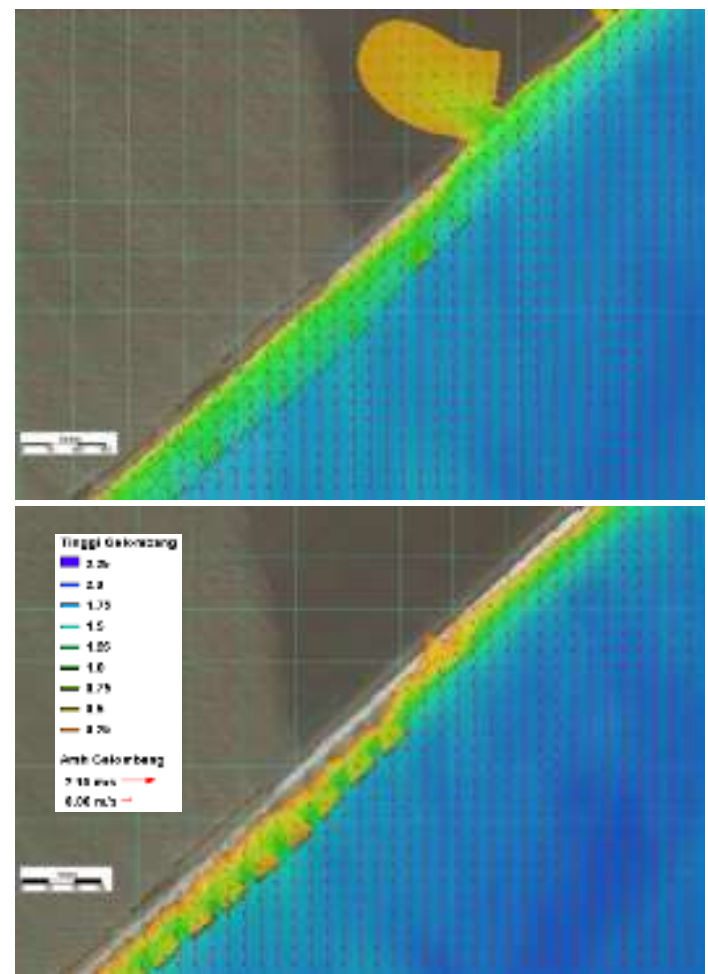

Gambar 5. Perbandingan model perubahan gelombang saat HWS (atas) dan MSL (bawah) dari arah selatan.

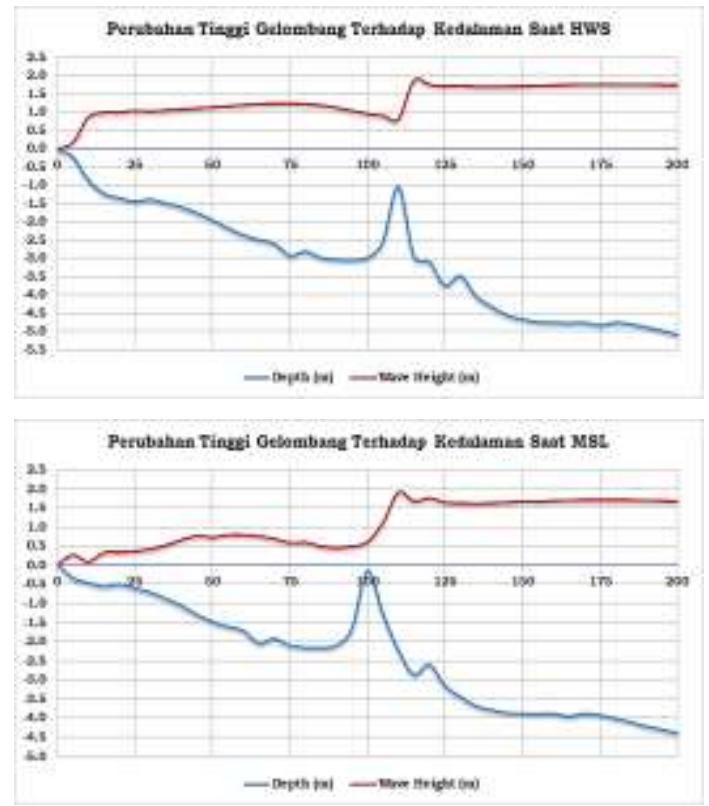

Gambar 6. Perbandingan perubahan tinggi gelombang saat HWS dan MSL di daerah sabuk pantai dari arah selatan. 
Hasil penelitian ini sama yang dilakukan oleh Baharuddin dkk. (2009) dengan menggunakan model RCPWave maupun Abdallah et al. (2006) menggunakan program ACES dengan menggunakan persamaan mild slope diselesaikan dalam tiga parameter yaitu tinggi gelombang, sudut gelombang dan fase gelombang. Gelombang akan pecah pada saat berbenturan dengan bangunan pantai.

\section{Model Penanganan Abrasi Pantai}

Berdasarkan hasil identifikasi yang telah dilakukan oleh KKP pada tahun 2017, bentuk penanganan pantai yang dapat dilakukan di Pantai Ujung Pandaran hanya berupa penanganan keras.

Bangunan pantai seperti groin, revetment dan tanggul banjir sesuai untuk melindungi perumahan atau bangunan dari erosi/ abrasi musiman, serangan gelombang atau banjir. Abrasi bangunan pantai dapat dihentikan untuk sementara namun abrasi sebenarnya akan terus terjadi karena jumlah sedimen yang berpindah di zona breaker tidaklah berubah. Akibatnya gerusan terus menerus terjadi di depan bangunan dan secara langsung mengancam bangunan yang terletak di pantai yang erosif karena kikisan oleh gerusan di depan bangunan. Upaya mitigasi dengan cara buatan perlu direncanakan secara cermat, karena dapat mengakibatkan terjadinya perubahan pola dan karakteristik gelombang yang dalam jangka panjang bisa mengakibatkan terjadinya erosi atau sedimentasi di tempat lain.

Hasil analisis matriks penilaian prioritas pembangunan bangunan pengaman pantai di Pantai Ujung Pandaran terbagi atas 3 (tiga) bagian yakni : Prioritas 1 pada bagian tengah, Prioritas II pada bagian barat (kawasan permukiman sampai sebelum garis pantai terputus) dan Prioritas III Bagian Timur (daerah Makam sampai Tanjung Pandaran), sebagaimana disajikan pada Gambar 7.

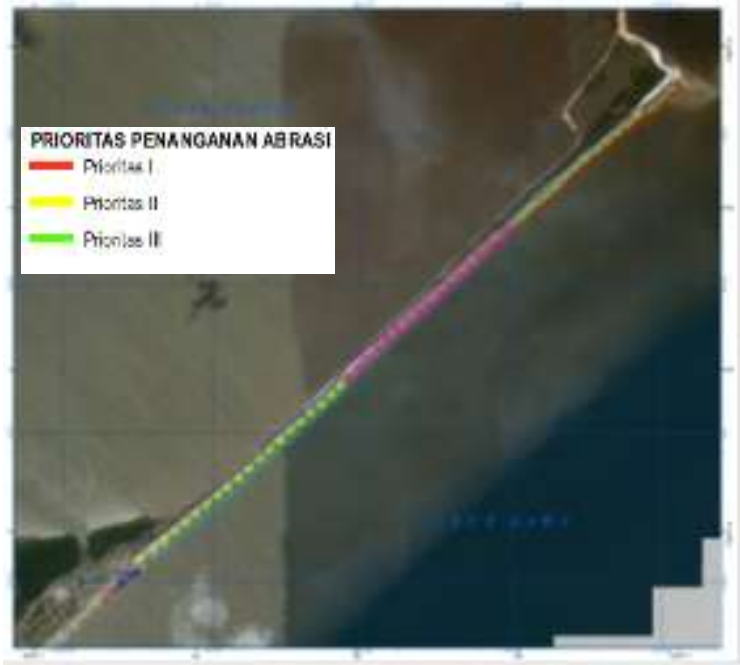

Gambar 7. Rekomendasi lokasi sabuk penanganan abrasi Pantai Ujung Pandaran

Untuk melihat tingkat pengaruh bangunan pantai terhadap dinamika hidrooseanografi terutama proses transformasi gelombang, maka dilakukan simulasi. Berdasarkan hasil review yang telah dijelaskan seperti di atas, bahwa posisi sabuk pantai yang telah dibangun pada tahun 2017 - 2018 berada pada kedalaman $2-2,5 \mathrm{~m} \mathrm{LWS}$ atau berada pada kedalaman 3,7 - 4,3 m HWS, sehingga posisi sabuk pantai masih tenggelam $1-1,5 \mathrm{~m}$ HWS. Kondisi tersebut menyebabkan gelombang akan sampai ke pantai di belakang bangunan, meskipun energi dan tinggi gelombang sudah berkurang. Akan tetapi energi gelombang masih cukup besar untuk menyebabkan abrasi pantai.

Oleh karena itu perlu dipertimbangkan lokasi penempatan sabuk terhadap kedalaman maupun lebar antar sabuk pantai untuk mengurangi dampak abrasi dan mempercepat proses terbentuk cuspate dan tombolo. Dengan asumsi bahwa tinggi bangunan sabuk pantai $2 \mathrm{~m}$ dengan panjang sabuk 60 meter dan lebar celah antar sabuk sebesar 15 dan $25 \mathrm{~m}$, maka pada saat pasang tertinggi bangunan tersebut maksimal $-0,5$ $m$ dari HWS, sehingga posisi sabuk berada pada kedalaman $(-2)-(-2,5) \mathrm{m}$ HWS atau $(-1,2)-(-1,7)$ MSL. Di wilayah pantai yang terputus, sabuk ditempatkan pada kedalaman -1,1 MSL, hal ini dilakukan agar 
pengaruh gelombang tidak semakin menggerus pantai, akan tetapi proses difraksi gelombang di belakang bangunan semakin kecil, sehingga proses terbentuknya sedimentasi semakin cepat dan garis pantai yang terputus akan tersambung kembali.

Prioritas I terletak pada wilayah bagian tengah (belakang Segmen 20 sampai Daerah Makam) sepanjang 1.463,90 m. Hasil simulasi gelombang baik dari arah selatan maupun tenggara menunjukan bahwa tinggi gelombang di belakang bangunan sabuk pantai pada saat HWS cukup besar mengalami penurunan tinggi gelombang $(<0,5 \mathrm{~m})$, sehingga energi gelombang dalam menggerus pantai akan semakin berkurang, akan tetapi di celah antara bangunan sabuk pantai, tinggi gelombang masih tinggi $(0,75-1 \mathrm{~m})$ dan cukup berpotensi dalam menggerus dan menyebabkan abrasi pantai. Hal ini sebagai akibat lebar antar sabuk masih cukup lebar yakni $25 \mathrm{~m}$, sedangkan pada daerah pantai yang terputus dibuat dengan jarak $15 \mathrm{~m}$ tinggi gelombang sedikit lebih kecil yakni $<0,75 \mathrm{~m}$, sebagaimana disajikan pada Gambar 8.

Untuk wilayah depan makam, panjang sabuk dibuat sepanjang $120 \mathrm{~m}$, terlihat bahwa gelombang tidak lagi terbentuk di posisi MSL, sedangkan pada saat HWS gelombang sudah sangat jauh menurun $(<$ 0,25 m). Dengan hasil simulasi tersebut menunjukan bahwa potensi abrasi akan sangat jauh menurun di wilayah ini.

Hasil ini dapat disimpulkan bahwa dengan posisi sabuk berada pada kedalaman $-1,2$ MSL dan lebar celah antar sabuk $<20 \mathrm{~m}$ akan lebih efektif dalam meredam energi gelombang dan abrasi pantai dibandingkan posisi sabuk pantai dibangun pada kedalaman yang tidak terlihat atau > 0,5 HWS.

Untuk mengetahui pola transformasi perubahan tinggi gelombang terhadap kedalaman dan posisi sabuk, maka dilakukan ekstraksi hasil model baik saat HWS maupun MSL untuk prioritas I dan II, sebagaimana disajikan pada Gambar 9.

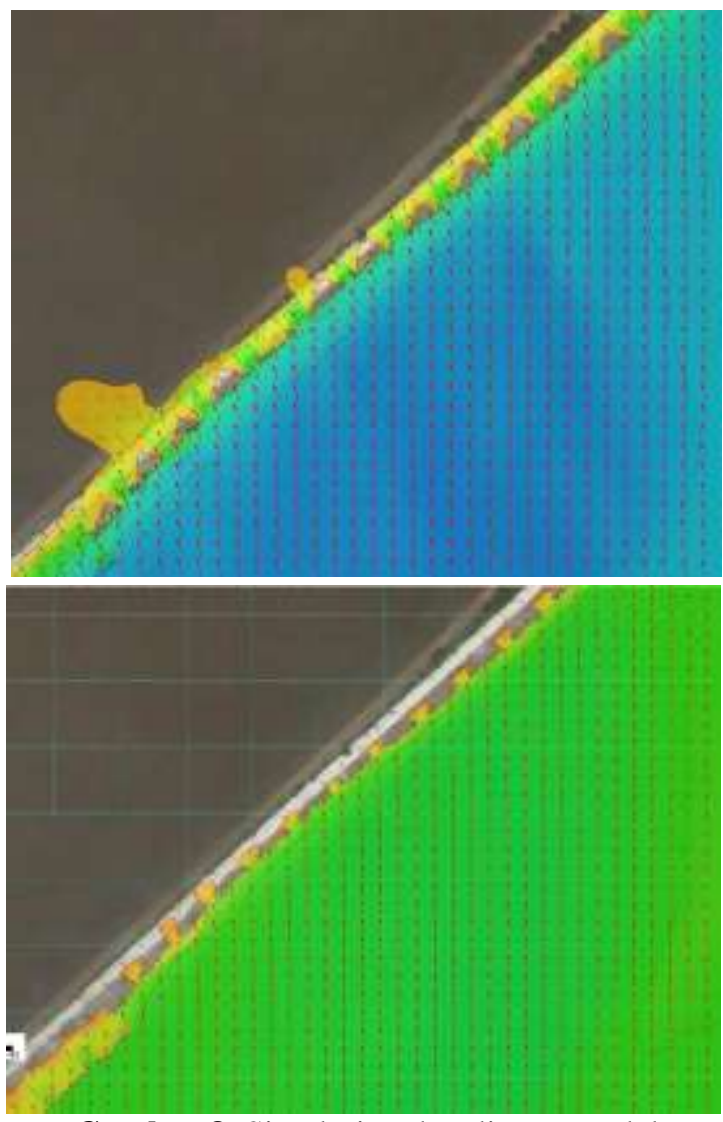

Gambar 8. Simulasi perbandingan model perubahan gelombang saat HWS dan MSL dari arah selatan.

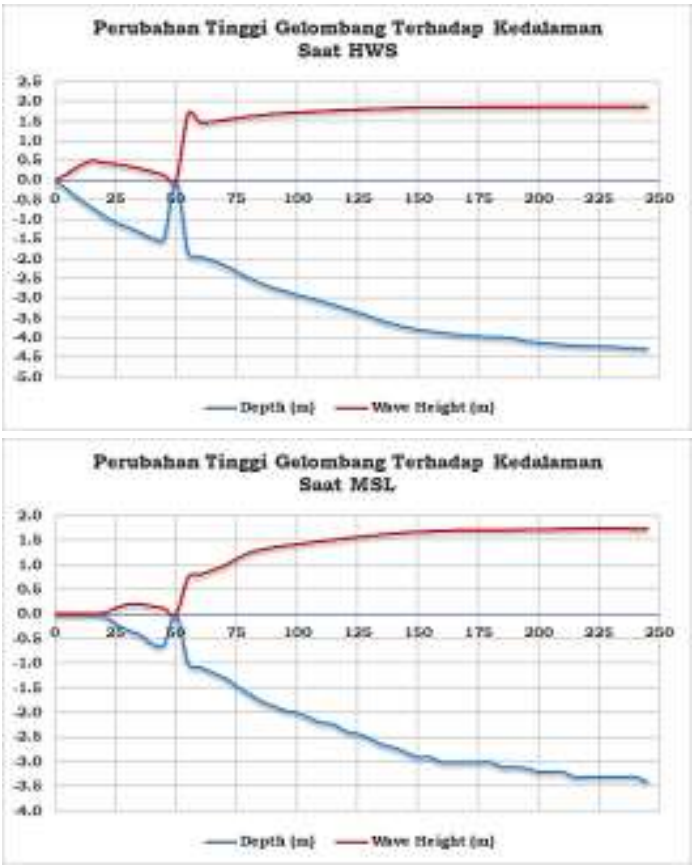

Gambar 9. Perbandingan model perubahan gelombang saat HWS dan MSL 
Gambar tersebut memperlihatkan bahwa terjadi penurunan tinggi gelombang di belakang bangunan sabuk pantai, dibandingkan dengan tinggi gelombang di antara celah sabuk pantai. Demikian halnya dengan adanya ketinggian sabuk pantai rencana yang akan dibangun pada kedalaman -1,1 MSL atau puncak sabuk pantai masih terendam minimal -0,5 HWS cukup efektif dalam meredam energi gelombang dan abrasi pantai.

Perubahan tinggi gelombang terjadi pada posisi sabuk pantai rencana saat HWS, gelombang sudah pecah dan ketika sampai di pantai ketinggiannya menurun $(<0,4 \mathrm{~m})$ dibandingkan pada posis antara celah sabuk, tinggi gelombangnya masih berada $>0,75 \mathrm{~m}$. Sedangkan saat MSL, gelombang sudah pecah jauh dari pasang tertinggi. Potensi terbentuknya cuspate dan lama kelamaan akan terbentuk tombolo di belakang bangunan sabuk pantai.

Untuk mengetahui perubahan garis pantai, maka dilakukan simulasi pengaruh bangunan sabuk pantai terhadap perubahan garis pantai. Simulasi dilakukan terhadap dua prioritas yakni Prioritas I dengan dua skenario dan Prioritas II dengan satu skenario, sebagaimana disajikan pada Tabel 1 dan Tabel 2.
Tabel 1. Skenario permodelan perubahan garis pantai di Prioritas I.

\begin{tabular}{lll}
\hline \multicolumn{1}{c}{ Uraian } & \multicolumn{2}{c}{ Skenario } \\
\hline $\begin{array}{l}\text { Panjang } \\
\begin{array}{l}\text { Segmen Sabuk } \\
\text { Pantai (m) }\end{array}\end{array}$ & $\begin{array}{l}\text { 60 m dan 120 m } \\
\text { (depan makam) }\end{array}$ & $\begin{array}{l}\text { 60 dan 120 } \\
\text { (depan } \\
\text { makam) }\end{array}$ \\
$\begin{array}{l}\text { Jumlah } \\
\text { Segmen Sabuk }\end{array}$ & \multicolumn{1}{c}{18} & 16 \\
Lebar Celah & $\begin{array}{l}\text { 10 m (wilayah } \\
\text { pantai } \\
\text { terputus/Segmen } \\
\text { Antar Segmen } \\
\text { (m) }\end{array}$ & 25 \\
& (Segmen 6-18) & \\
\hline
\end{tabular}

Tabel 2. Skenario permodelan perubahan garis pantai di Prioritas II.

\begin{tabular}{lc}
\hline \multicolumn{1}{c}{ Uraian } & Skenario \\
\hline Panjang Segmen & $60 \mathrm{~m}$ (Segmen 1) dan \\
Sabuk Pantai (m) & $40 \mathrm{~m}$ (Segmen 2-18) \\
Jumlah Segmen Sabuk & 18 \\
Lebar Celah Antar & 45 \\
Segmen (m) & \\
\hline
\end{tabular}

Berdasarkan skenario tersebut, diperoleh hasil yang menunjukan bahwa pada Skenario 1 dengan lebar celah $10 \mathrm{~m}$, tingkat abrasi jauh lebih kecil 2,1 $\mathrm{m}$ banding $7 \mathrm{~m}$, akan tetapi untuk tingkat sedimentasi atau terbentuknya cuspate pada Skenario 2 lebih besar 9,5 $\mathrm{m}$ berbanding 6,4 $\mathrm{m}$. Sedangkan di depan makam, terbentuk cuspate sejauh 5,3 $\mathrm{m}$ di Skenario $1(20 \mathrm{~m})$ dan 3,6 $\mathrm{m}$ di Skenario $2(25 \mathrm{~m})$, sebagaimana disajikan pada Tabel 3.

Tabel 3. Hasil perbandingan abrasi dan sedimentasi pada berbagai skenario. A: abrasi; S: sedimentasi

\begin{tabular}{ccccccc}
\hline & \multicolumn{5}{c}{ Skenario 1 } \\
Segmen & \multicolumn{2}{c}{$(10$ meter $)$} & \multicolumn{2}{c}{$(20$ meter $)$} & \multicolumn{2}{c}{$(25$ meter $)$} \\
& $\mathrm{A}(\mathrm{m})$ & $\mathrm{S}(\mathrm{m})$ & $\mathrm{A}(\mathrm{m})$ & $\mathrm{S}(\mathrm{m})$ & $\mathrm{A}(\mathrm{m})$ & $\mathrm{S}(\mathrm{m})$ \\
\hline 1 & 2,1 & 6,4 & & & 7 & 9,5 \\
3 & 4,3 & 6 & & & 7,7 & 8,1 \\
5 (ujung HWS Skenario 2) & 5,1 & 6,3 & & & 7,8 & 8,3 \\
7 (ujung HWS Skenario1) & 4,6 & 5,7 & & & 6,8 & 8 \\
10 & & & 6,7 & 6 & 8,6 & 8 \\
$17 / 15$ (makam) & & & 6,2 & 5,3 & 7,3 & 3,6 \\
$18 / 16$ & & & 6,8 & 1 & 7,3 & 1 \\
\hline
\end{tabular}

Karena dalam model memiliki keterbatasan tanpa masukan pengaruh dari arus hanya mempertimbangkan gelombang, sehingga kemungkinan besar untuk terbentuk cuspate dan tombolo di wilayah pantai yang terputus sangat besar. Hal ini diduga karena pola arus dari teluk dominan mengarah ke arah tenggara saat surut dan posisi sabuk pantai rencana dipasang berhadapan dengan arah aliran tersebut, sehingga aliran keluar yang membawa sedimen akan tertahan oleh bangunan sabuk dan lama kelamaan tombolo akan terbentuk dan 
pantai yang terputus akan tersambung kembali.

Untuk simulasi perubahan garis pantai 1 tahun dan 3 tahun diperlihatkan pada Tabel 4. Hasil ini menunjukan bahwa proses terbentuknya cuspate akan selalu bervariasi berdasarkan arah datang gelombang dan bentuk serta penempatan lokasi sabuk pantai rencana. Lokasi terbentuknya cuspate terbesar terjadi pada sabuk pantai rencana daerah depan makam yakni sebesar $15 \mathrm{~m}$.

Tabel 4. Hasil perubahan garis pantai di Prioritas I dengan simulasi 1 tahun - 3 tahun.

\begin{tabular}{ccccc}
\hline \multirow{2}{*}{ Segmen } & \multicolumn{2}{c}{ 1 Tahun } & \multicolumn{2}{c}{3 Tahun } \\
& Abrasi (m) & Sedimentasi $(\mathrm{m})$ & Abrasi (m) & Sedimentasi $(\mathrm{m})$ \\
\hline 10 meter & & & & \\
1 & 2,1 & 6,4 & 3,8 & 10 \\
5 & 5,1 & 6,3 & 6,8 & 7,7 \\
10 & 6,7 & 6 & 7,2 & 7,1 \\
20 meter & & & & 6 \\
14 & 7,7 & 7,5 & 9 & 15 \\
17 & 6,2 & 5,3 & 10,2 & 8 \\
18 & 6,8 & 5 & 15,7 & \\
\hline
\end{tabular}

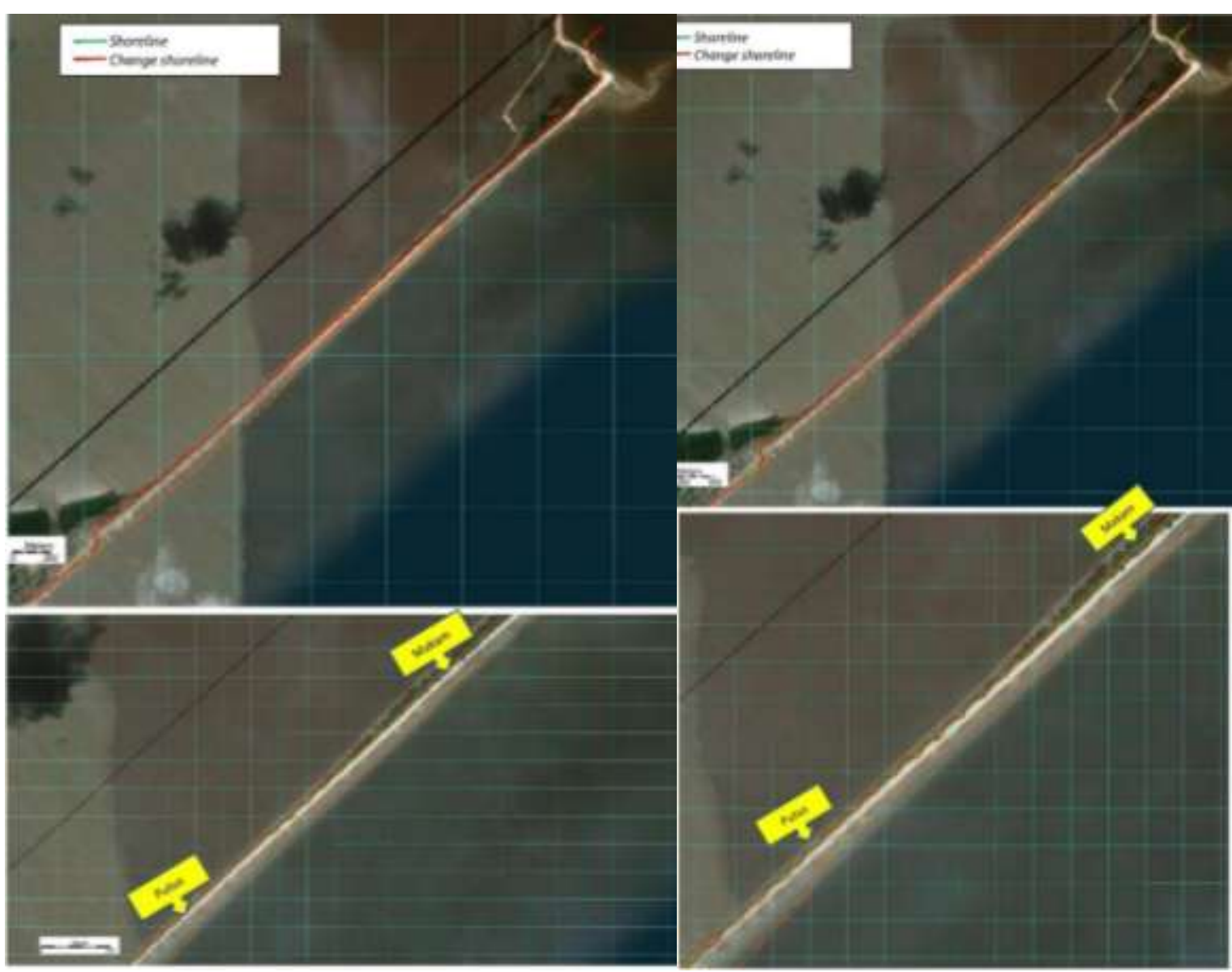

Gambar 10. Hasil simulasi selama 1 tahun dan 3 tahun model perubahan garis pantai saat posisi HWS di Prioritas 1 Skenario 1 sampai ke daerah makam.

Gambar 10 - 11 memperlihatkan skenario apabila Segmen 17 dan 18 yakni di depan makam tidak dibangun. Gambar tersebut menunjukan bahwa apabila wilayah makam tidak ditangani dengan segera maka kemungkinan besar wilayah ini akan terkena abrasi yang cukup besar $(5,3 \mathrm{~m})$, dengan pada Agustus 2018 terlihat posisi bangunan tersisa 1 meter dari pasang tertinggi. 


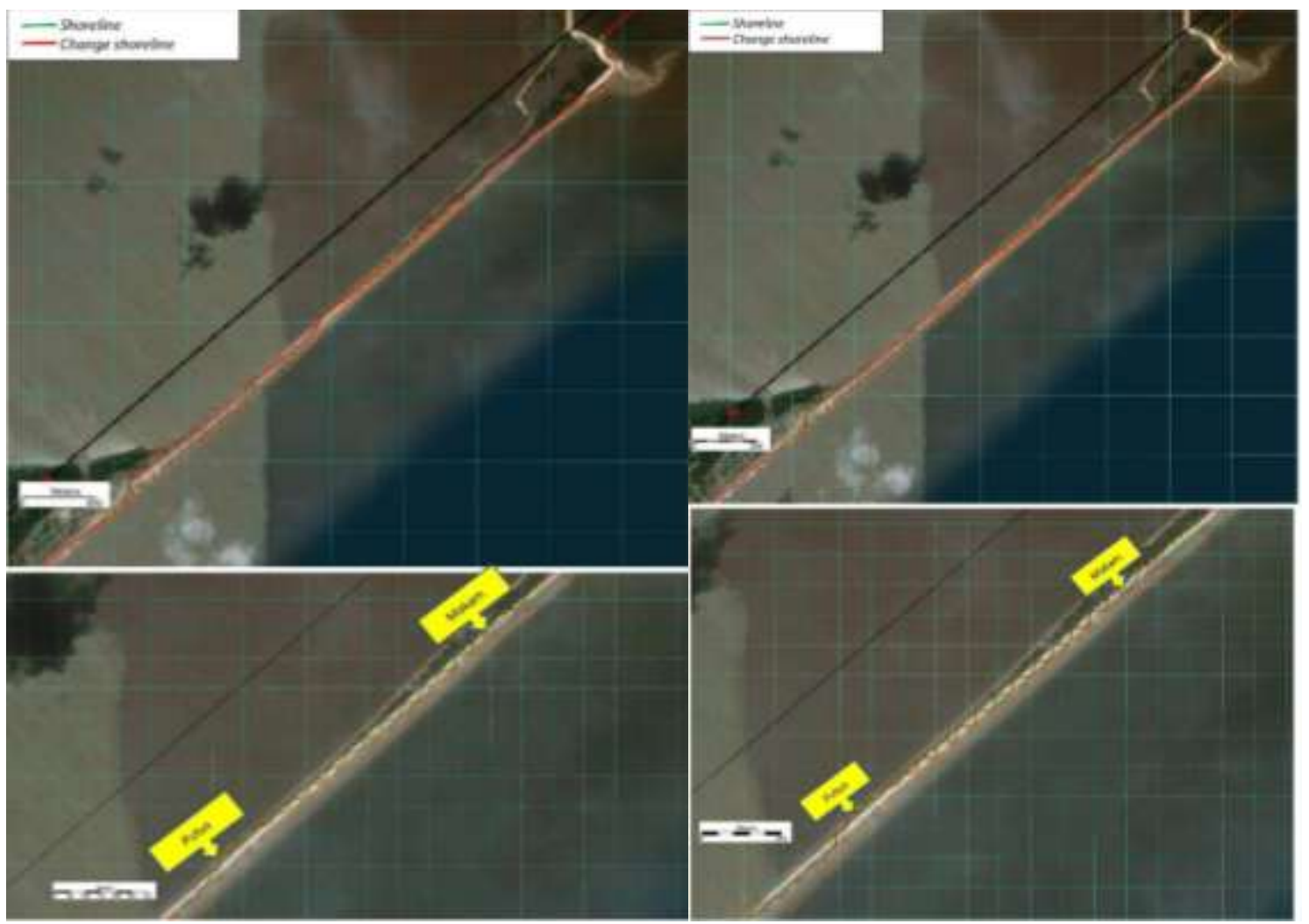

Gambar 11. Hasil simulasi selama 1 tahun dan 3 model perubahan garis pantai saat posisi MSL di Prioritas 1 Skenario 1 sampai ke daerah makam.

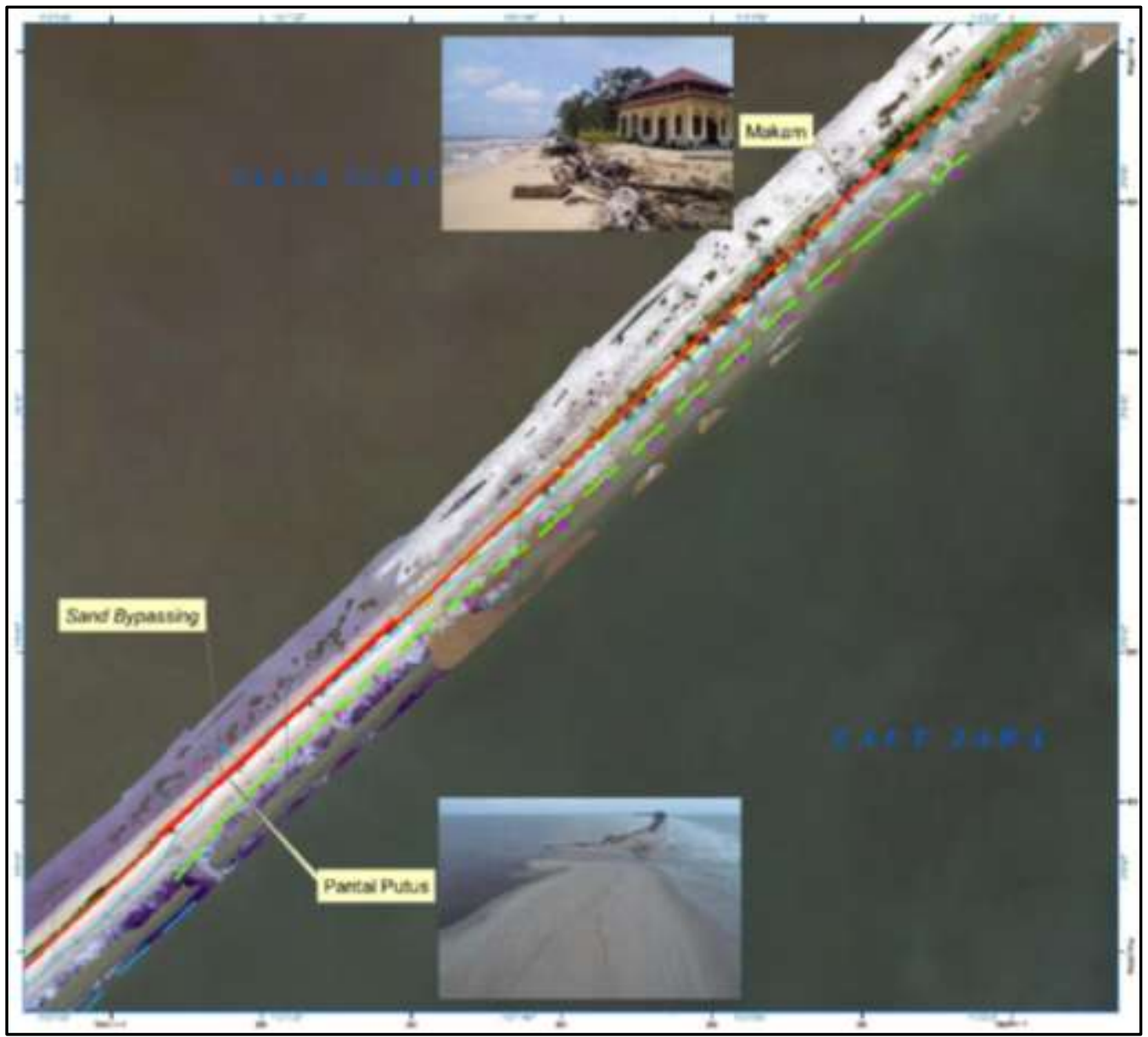

Gambar 12. Rekomendasi penanganan abrasi pantai di Prioritas I Pantai Ujung Pandaran. 
Hasil model tersebut menunjukan bahwa abrasi masih akan terjadi di daerah celah sabuk pantai rencana, sehingga untuk mengurangi abrasi tersebut diperlukan penanganan berupa pemasangan revetment atau bronjong di sepanjang celah sabuk pantai rencana, seperti diperlihatkan pada Gambar 12.

\section{Kesimpulan}

Pada saat kondisi pasang tertinggi (HWS) posisi sabuk pantai yang dibangun sebelumnya masih tenggelam sedalam 1 1,4 meter. Akibatnya gelombang masih dapat mencapai daratan pantai dan sabuk pantai belum mampu secara maksimal meredam energi gelombang ekstrim sehingga abrasi masih terjadi.

Pembangunan pengaman pantai dalam bentuk sabuk pantai untuk prioritas I sebanyak 18 segmen dengan lebar celah antar segmen maksimum $10 \mathrm{~m}$ dari pantai yakni Segmen $1-6$ dengan panjang segmen $\pm 60 \mathrm{~m}$, sedangkan segmen $7-18$ dengan lebar maksimum $20 \mathrm{~m}$. Khusus segmen 17 yakni di depan makam, panjang sabuk pantai sebesar $120 \mathrm{~m}$.

Jika tinggi rencana bangunan sabuk pantai $2 \mathrm{~m}$, maka penempatan bangunan sabuk pantai pada posisi HWS, direkomendasikan puncak tub maksimal masih terendam $-0,5$ m HWS. Hasil analisis model gelombang menunjukan di puncak tub gelombang sudah pecah, sehingga tinggi dan energi gelombang di belakang bangunan sudah sangat berkurang dan pengerusan gelombang terhadap pantai pada posisi pasang tertinggi juga akan sangat berkurang. Hasil model perubahan garis pantai menunjukan daerah belakang bangunan sabuk pantai maupun di pantai akan terbentuk cuspate dan lama-kelamaan akan terbentuk tombolo.

Penempatan sabuk pantai di Prioritas I direkomendasikan pada kedalaman 0,9 1,5 MSL. Wilayah pantai di bagian antar celah sabuk pantai, resiko untuk terjadinya abrasi akan tetap terjadi, sehingga untuk mengurangi abrasi tersebut diperlukan pemasangan revetment berupa tumpukan batu/ beton bertingkat.

\section{Ucapan Terima Kasih}

Ucapan terima kasih ditujukan kepada Direktorat Pendayagunaan Pesisir dan Pulau-pulau Kecil Ditjen Pengelolaan Ruang Laut Kementerian Kelautan dan Perikanan atas penyediaan data dalam penelitian ini.

\section{Daftar Pustaka}

Abdallah, A.M., Sharaf El-Din, S.H., Shereet, S.M. 2006. Analysis Wave Observations and Wave Transformations in Abu-Qir Bay, Egypt, Egyptian Journal Aquatic Research, 32 (1):22-33.

Azhar, M.R., Suntoyo, Musta'in, M. 2012. Analisa Perubahan Garis Pantai Tuban, Jawa Timur dengan Menggunakan Empirical Orthogonal Function (EOF). JURNAL Teknik ITS, 1(1):G286-G291.

Aziz, M.K., Lesmi, S.A., Pranoto, S., dan Parmantoro, P.N. 2016. Penanganan Abrasi Pantai Desa Sei Raja Kabupaten Sukamara Kalimantan Tengah. Jurnal Karya Teknik Sipil, 5(2):63-74.

Baharuddin., Pariwono, J.I., Nurjaya, I.W. 2009. Pola Transformasi Gelombang Dengan Menggunakan Model RCPWave pada Pantai Bau-Bau, Provinsi Sulawesi Tenggara. E-Jurnal Ilmu dan Teknologi Kelautan Tropis, 1(2):60-71.

[CHL] Coastal Hydraulic Laboratory. 2006. Coastal Engineering Manual, Part I-VI. Washington DC: Department of the Army. U.S. Army Corp of Engineers.

[DKP] Dinas Kelautan dan Perikanan Provinsi Kalimantan Tengah. 2017. Rencana Zonasi Wilayah Pesisir dan Pulau-Pulau Kecil Provinsi Kalimantan Tengah. 
Djunaedi, A. dan Basuki, M.N. 2002. Perencanaan Pengembangan Kawasan Pesisir. Jurnal Teknologi Lingkungan, 3(3):225-231.

[KKP] Kementerian Kelautan dan Perikanan. 2018. Review terhadap Perencanaan Pembuatan Sabuk Pantai untuk Adaptasi Perubahan Iklim di Kabupaten Kotawaringin Timur. Direktorat Jenderal Pengelolaan Ruang Laut Direktorat Pendayagunaan Pesisir dan Pulau-Pulau Kecil. Jakarta.

Munandar, M., dan Kusumawati, I. 2017. Studi Analisis Faktor Penyebab dan Penanganan Abrasi Pantai di Wilayah Pesisir Aceh Barat. Jurnal Perikanan
Tropis, $\quad 4(1): 47-56$.

DOI: https://doi.org/10.35308/jpt.v4i1.55

Supriyanto, A. (2003). Analisis Abrasi Pantai dan Alternatif Penanggulangannya di Perairan Pesisir Perbatasan Kabupaten Kendal-Kota Semarang. Tesis. Program Pascasarjana Universitas Diponegoro. Semarang.

*) Artikel ini telah dipresentasikan di Seminar Nasional Geofisika 2019 yang dilaksakan oleh Dept. Geofisika FMIPA Universitas Hasanuddin di Science Building FMIPA Universitas Hasanuddin pada tanggal 26 Oktober 2019. 